\title{
Staying Responsible Within the HealthCARE IndUSTRY In THE ERA OF THE Responsible Corporate OfFICER DOCTRINe
}

\author{
Jane Kim J.D.* \\ TABLE OF CONTENTS
}

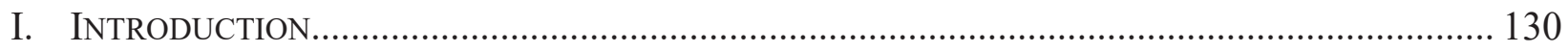

II. Government Efforts to Combat Fraud And Abuse Within the Health Industry.. 133

III. The DeVElopment of THE Responsible Corporate OfFicer Doctrine.......................... 136

A. Development of the Responsible Corporate Officer Doctrine

B. Who is Responsible Under the Responsible Corporate Officer Doctrine and Who Else Should be Held Responsible?

C. Industries Most Affected by the Responsible Corporate Officer Doctrine

D. Defenses to Responsible Corporate Officer Doctrine

E. Civil Remedies of Exclusion

1. Exclusions of Individuals by the OIG

2. Exclusion of Entities by DOJ

IV. PuRdue AND OXYCONTIN.
A. OxyContin
B. Sales Personnel, Misbranding and Inadequate Compliance Program
C. The Trio's Defenses
D. Others Involved in the OxyContine and the Illicit Drug Scandal
E. The Trio's Plea Deal
F. Considering and Accepting the Trio's Guilty Plea
G. RCOD Resulting in Exclusion Does Not Violate Due Process
H. Conflict of Interest and Indemnification

V. COMPliance Programs 156

VI. CONCLUSION. 159 


\section{INTRODUCTION}

Fraud and abuse in the healthcare system has reached staggering proportions. ${ }^{1}$ The healthcare industry as a whole comprises $18 \%$ of the total GDP. ${ }^{2}$ In 2015 , the U.S. government allocated a third of the $\$ 3.7$ trillion federal budget, or $\$ 1,010$ billion, ${ }^{3}$ to Medicare and Medicaid programs. Fraud and other misconduct across the entire health system accounts for up to $\$ 272$ billion or more than $25 \%$ of overall healthcare budget. ${ }^{4}$ The situation has become so dire that there is even a most wanted healthcare fugitives list seeking people's assistance to apprehend health fraud fugitives. ${ }^{5}$

Despite the government's aggressive efforts to combat fraud and abuse within the health industry and doing so successfully, ${ }^{6}$ it never seems sufficient enough. Flowing from those efforts to combat fraud and abuse, the Office of Inspector General ("OIG") has pricked our consciousness with the Responsible Corporate Officer Doctrine ("RCOD"), whereby corporate officers are personally liable for the conduct of their companies. Daniel R. Levinson, Inspector General of the Department of Health and Human Services ("HHS"), in his keynote address called for an "individual accountability," stating that the "OIG is focused on holding Responsible Corporate Officials accountable for healthcare fraud." 7

Under the RCOD, "corporate officers are subject to both civil and criminal liability," misdemeanor and felony convictions, "for corporate violations of statutes affecting public

* Jane Kim is a law partner at KYZ Law P.C. focusing on civil litigation and healthcare regulatory and compliance matters. She has received her undergraduate degree at The School of the Art Institute of Chicago, J.D. degree at John Marshal Law School of Chicago and an LL.M. in Health Law with Concentration in Compliance Studies at Loyola University Chicago School of Law, further including a Certificate in Healthcare Compliance. My gratitude goes to Prof. Larry Singer, Director of the Beazley Institute for Health Law and Policy, for posing difficult questions.

1 See United States v. Esformes et al., U.S. DeP'T JUST., https://www.justice.gov [https://perma.cc/B97A-ZB2H] (last visited October 4, 2016) (The largest healthcare fraud scheme to date was primarily perpetrated by a single individual and allegedly involved over $\$ 1$ billion in "services that were medically unnecessary, never provided, and procured through the payment of kickbacks and bribes.").

${ }^{2}$ The Economic Case for Healthcare Reform, WHITE House, https://www.whitehouse.gov [https://perma.cc/GL9U-J8NZ] (last visited Aug. 28, 2015).

3 Office of Budget, HHS FY2015 Budget in Brief, HHS.gOv, http://www.hhs.gov/ [https://perma.cc/8NKF-DDZ7] (last updated June 4, 2014).

${ }^{4}$ The $\$ 272$ billion swindle: Why thieves love America's health-care system, ECONOMIST (May 31, 2014), http://www.economist.com [https://perma.cc/6Y2M-W9A2].

${ }^{5}$ The fugitive list and its sought-after "members" haven't changed since 2013. OIG Most Wanted Fugitives, U.S. DeP’T HeAlth \& Hum. SeRvs: OfF. InSPECTOR Gen., http://oig.hhs.gov/ [https://perma.cc/63DW-S8XQ] (last visited Aug. 1, 2015).

${ }^{6}$ U.S. Dep't of Just., Justice Department Recovers Over \$4.7 Billion from False Claims Act Cases in Fiscal Year 2016, Third Highest Annual Recovery in FCA History, https://www.justice.gov [https://perma.cc/8PTZ-P5U5].

${ }^{7}$ OfFice of Inspector Gen., Highlights of the Keynote AdDress Delivered by Daniel R. LeVinson, InSPECtor General of the Department of Health \& Human Services, at the Healthcare Compliance Association Annual Compliance Institute 5 (Apr. 19, 2010), https://oig.hhs.gov/ [https://perma.cc/28GX-W98U]. 
welfare." 8 Public welfare laws include "environmental laws . . . securities laws, as well as consumer fraud, deceptive mortgage lending practices, antitrust violations, failures in recordkeeping of controlled substances, sales tax violations, liability under the Sarbanes-Oxley Act . . .." They also encompass health-related laws under the Food and Drug Administration ("FDA"), the Health Insurance Portability and Accountability Act ("HIPAA"), and various fraud and abuse laws impacting the health industry consisting, primarily, of the durable equipment, medical devices, pharmaceutical industry, and providers of healthcare.

The RCOD and "strict liability misdemeanor" offenses are terms that are often used interchangeably. The notion of being held strictly liable for something criminally is unsettling, and it is instilling fear and helplessness in corporate officers. ${ }^{10}$ Often this phrase is used in reference to the frequently invoked Section on Prohibited Acts pursuant to the FDA. ${ }^{11}$ Of note, however, the Section does not use the term "strict liability." Therefore, the phrase "strict liability misdemeanor" is a misnomer or an industry phrase that is not proper at law although referenced widely by courts and legal professionals alike.

"Strict liability" is a legal term of art and was developed to avoid proving the elements of negligence in a civil case. Strict liability is designed to regulate actions, behavior and activities that are per se unusually dangerous or harmful. On the other hand, "misdemeanor" is a criminal phrase that, as a way of punishment, carries a term of imprisonment under one year. Conflating these two very distinct legal concepts (civil and criminal) into one phrase is oxymoronic, and the RCOD may be to blame, in that under the RCOD a corporate officer may be facing either civil or criminal repercussions, or both, without intent to commit the act. A civil remedy is by way of exclusion from participation in federal and state healthcare programs and/or a fine; and a criminal remedy is a term of years in prison or probation and/or restitution.

Whenever the government invokes the RCOD, however, it is "making an entire industry nervous," 12 in that it is commonly perceived as the "crime of doing nothing." 13 For instance, with regard to drugs in the health field, "[The] government need not prove knowledge or awareness that the drugs are misbranded or an intent to deceive or defraud" in order to impose criminal liability

${ }^{8}$ Id.

${ }^{9}$ Michael E. Clark, The Responsible Corporate Officer Doctrine, A Re-emergent Threat to General Counsel and Corporate Officers, 14 J. HeAlthCARE COMPlance 5, 6 (2012), http://www.duanemorris.com/ [https://perma.cc/63M8-K5UT] (quoting Martin Petrin, Circumscribing the "Prosecutor's Ticket to Tag the Elite": A Critique of the Responsible Corporate Officer Doctrine, 84 TEMPLE L. REV. 283, 289-290 (2011)).

10 Brent J. Gurney et AL., The CRime of Doing Nothing: Strict Liability for CORPORATE OFFICERS UNDER THE FDCA F-9 (2007), http://www.wilmerhale.com/ [https://perma.cc/SW5D-RQT2].

1121 U.S.C. $\$ 331(2015)$.

12 Jason M. Crawford, A Bitter Pill for the Pharmaceutical Industry? HHS-OIG's Enforcement of the Responsible Corporate Officer Doctrine, 17 QuinNIPIAC HEALTH L.J. 45, 62 (2014), https://www.qu.edu/ [https://perma.cc/CN3C-UF7D]; quoting Ricardo Alonso-Zaldivar, Feds now target execs, not just companies, in health frauds, USA TODAY (May 31, 2011, 3:57 PM), http://usatoday30.usatoday.com [https://perma.cc/EL63-SP36]).

${ }^{13}$ Clark, supra note 9, at 5 (quoting Gurney et al., supra note 10). 
for misbranding drugs in interstate commerce. ${ }^{14}$ "The word 'responsible' in the doctrine's name does not mean that the individual is responsible for the misconduct..." 15 That is, "while a director will be safe from civil liability by operation of the 'business judgment rule' when he or she fulfills his or her . . oversight duties, the director can be held criminally responsible by operation of the $\mathrm{RCO}$ doctrine even if he or she did not know that company employees had violated public welfare laws." 16

Thus, one does not have to participate in nefarious activities to be individually and criminally responsible under the RCOD. A valid concern arises that nothing but humility and self-restraint stand in the way of government overreaching. Understandably, this is an unsettling thought.

This paper explores whether the fears of the RCOD within the health industry are misplaced. Part I reviews the government's efforts to combat fraud and abuse within the health industry. Part II tracks the development of the RCOD over time, including its progression to exclude entities and individuals from participation in federal reimbursement programs as one of the most potent remedies to combat fraud and abuse. Part II further explores who may actually be found responsible under the RCOD, together with a proposed solution to an obvious constitutional challenge (subsection B); industries most affected by the RCOD to date (subsection C); and available defenses under the RCOD (subsection D). In Part III, the paper examines the muchcriticized case of Purdue Frederick Company and the exclusion from participation in federal programs of its corporate officers, ${ }^{17}$ advocating the minority argument that the government appropriately utilized the remedies available to it under the RCOD given the applicable law and facts of the case. Part III further explores conflict of interest and indemnification issues arising under the RCOD. Finally, Part IV discusses how robust and effective compliance programs are one of the most effective ways to avoid becoming a target under the RCOD.

${ }^{14}$ United States v. Articles of Drug, 825 F.2d 1238, 1246 (8th Cir. 1987).

${ }^{15}$ Kevin LaCroix, More About the Responsible Corporate Officer Doctrine, D \& O DIARY (March 8, 2010), http://www.dandodiary.com/ [https://perma.cc/M3U4-8DS9] (emphasis added).

${ }^{16}$ Clark, supra note 9, at 6 (emphasis added).

17 United States v. Purdue Frederick Co., 495 F. Supp.2d 569 (W.D. Va. 2007); see also Friedman v. Sebelius, 755 F. Supp. 2d 98, 102 (D.D.C. 2010), rev'd, 686 F.3d 813 (D.C. Cir. 2012). 


\section{Government EfForts to Combat Fraud And Abuse Within the Health Industry}

Multiple agencies within the HHS ${ }^{18}$ may utilize the RCOD in enforcing its rules, including the Office of Civil Rights ("OCR") ${ }^{19}$, the Office of Inspector General ("OIG") ${ }^{20}$, and the FDA ${ }^{21}$; separately, from the HHS, the Department of Justice ("DOJ") ${ }^{22}$ may also rely upon the RCOD as a vehicle to enforce health-related laws.

The Secretary of $\mathrm{HHS}^{23}$ and the Attorney General ${ }^{24}$ joined their efforts to combat healthcare waste, fraud, and abuse by cracking down on fraud perpetrators with the creation of the Healthcare

${ }^{18}$ HHS combats fraud and abuse within the healthcare industry through the Office of Inspector General and the following agencies: (a) Office of the General Counsel; (b) Administration for Community Living; (c) Food and Drug Administration; (d) Centers for Medicare \& Medicaid Services.

${ }^{19}$ U.S. DeP'T Health \& Hum. Servs: Office For Civil Rights, Organizational Chart, http://www.hhs.gov/ [https://perma.cc/XM73-EHED] (last visited Aug. 28, 2015).

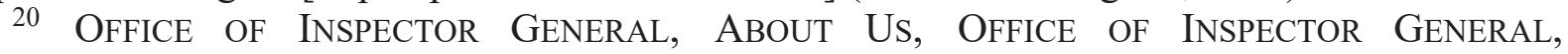
http://oig.hhs.gov [https://perma.cc/48BH-UEXU] (stating that OIG was established in 1976 and "has been at the forefront of the Nation's efforts to fight waste, fraud and abuse in Medicare, Medicaid and more than 100 other HHS programs. [Its] mission is to protect the integrity of Department of Health \& Human Services ("HHS") programs as well as the health and welfare of program beneficiaries.").

${ }^{21}$ History, U.S. FoOD \& DRUG ADMIN., http://www.fda.gov [https://perma.cc/RR95-NPDB] (last visited Aug. 28, 2015) ("The Food and Drug Administration is the oldest comprehensive consumer protection agency in the U. S. federal government. Its origins can be traced back to the appointment of Lewis Caleb Beck in the Patent Office around 1848 to carry out chemical analyses of agricultural products.").

22 The Department of Health and Human Services and The Department of Justice Health Care Fraud and Abuse Program Annual Report for FY 2000, U.S. DEP'T OF JUSTICE, http://www.justice.gov/ [https://perma.cc/R7ZD-6B5Z] (last visited Aug. 28, 2015) (noting that the Department of Justice consists of the following agencies that are assigned with the duties to combat fraud and abuse within the healthcare industry: (a) United States Attorneys; (b) Civil Division; (c) Criminal Division; (d) Civil Rights Division; (e) Nursing Home and Elder Justice Initiative; (f) Justice Management Division).

${ }^{23}$ HHS Agencies and Offices, U.S. DeP'T OF HeAlTH \& HuMAN SERVS., http://www.hhs.gov/ [https://perma.cc/UTS6-C49V] (noting that The Office of the Secretary ("OS"), HHS's chief policy officer and general manager, administers and oversees the organization, its programs and its activities).

${ }^{24}$ About DOJ, U.S. DEP'T OF JUSTICE, http://www.justice.gov/about [https://perma.cc/C67JVZ77] (noting that The Judiciary Act of 1789, ch. 20, sec. 35, 1 Stat. 73, 92-93 (1789) created the Office of the Attorney General, which was originally a one-person part-time position. In 1870 , Congress passed the Act to Establish the Department of Justice, ch. 150, 16 Stat. 162 (1870) (the 1870 Act) creating "an executive department of the government of the United States" with the Attorney General as its head). 
Fraud Prevention and Enforcement Action Team ("HEAT"). ${ }^{25}$ HEAT created Medicare Fraud Strike Forces focusing on identified "hot spots"- Miami, Los Angeles, Detroit, Houston, Brooklyn, Baton Rouge, Tampa, Dallas, and Chicago. ${ }^{26}$ The Strike Force pursues cases involving 100 percent fraud, i.e., those cases where defendants do not provide any legitimate services to beneficiaries. ${ }^{27}$ Since its inception in 2007, Strike Force operations "charged almost 1,000 individuals for fraud schemes involving more than $\$ 2.3$ billion in claims." 28

In addition to HEAT, the OCR under the HHS umbrella, regulates covered entities under the Health Insurance Portability and Accountability Act of 1996 ("HIPAA") and the Health Information Technology for Economic and Clinical Health Act ("HITECH Act"), such as health plans, healthcare clearinghouses and healthcare providers. ${ }^{29}$ These entities and their business associates are covered under HIPAA if they "create, receive, maintain, or transmit protected health information." 30

Further, HIPAA established a national Health Care Fraud and Abuse Control Program ("HCFAC or the Program") under the joint direction of the Attorney General and the Secretary of the HHS, acting through the Inspector General, designed to coordinate federal, state and local law enforcement activities with respect to healthcare fraud and abuse. ${ }^{31}$ HCFAC allocated $\$ 2.4$ billion in $2015^{32}$ (an increase of almost $\$ 1$ billion from the year prior) ${ }^{33}$ to the HHS ${ }^{34}$ and DOJ to oversee the efforts of combating fraud and abuse within the healthcare industry. ${ }^{35}$ The government's use

${ }^{25}$ Improving Efforts to Combat Healthcare Fraud: Hearing Before the Comm. on Ways and Means, Subcomm. on Oversight, 112th Cong. (2011) (statement of Lewis Morris, Chief Counsel, Office of the Inspector General, Dep't of Health and Human Servs.), http://www.hhs.gov [http://perma.cc/6XJU-VSYP] (last visited Aug. 1, 2015). (noting that this announcement was made on May 20, 2009).

${ }^{26} I d$.

${ }^{27} \mathrm{Id}$.

${ }^{28} I d$.

${ }^{29}$ Health Insurance Portability and Accountability Act, 45 C.F.R. $\$ 160.103$ (1996) (noting that the OCR, the Office of Inspector General ("OIG") and the Department of Justice ("DOJ") are responsible for HIPAA enforcement).

${ }^{30} \mathrm{Id}$.

${ }^{31}$ U.S. Dep' t of Justice, Annual Report of the Departments of Health and Human SERVICES AND JUSTICE 1 (2015), https://oig.hhs.gov [https://perma.cc/FR7F-EV5Y] (last visited Aug. 1, 2015).

32 Dep't of Health and Human Services and the DeP' t of Justice, Health Care Fraud and Abuse Control Program: AnNUAL Report for Fiscal Year 20151 (2016), https://oig.hhs.gov/ [https://perma.cc/GYN4-BCRF] (last visited Sept. 24, 2016).

${ }^{33}$ U.S. DEP'T OF JUSTICE, supra note 31 , at 1.

${ }^{34}$ HHS Historical Highlights, U.S. DeP'T OF HEALTH \& Human SERVs., http://www.hhs.gov/ [https://perma.cc/VL3Y-YD9Z] (noting that the very first activity that created today's HHS was in 1798 with the "[p] assage of an act for the relief of sick and disabled seamen, which established a federal network of hospitals for the care of merchant seamen." Today, HHS "is the nation's principal agency for protecting the health of all Americans and providing essential human services."').

${ }^{35}$ U.S. DEP'T OF JUSTICE, supra note 32, at 1. 
of HIPAA to recoup from those violating the law has been effective. ${ }^{36}$ The U.S. government realizes an almost seven-to-one return on every dollar invested in HCFAC. ${ }^{37}$ Thus, "[ $\left.\mathrm{t}\right]$ he HCFAC account has returned over $\$ 29.4$ billion to the Medicare Trust Funds since the inception of the Program in 1997." 38

The OIG, another agency under the HHS, "was established . . . to identify and eliminate fraud, waste, and abuse in the Department's programs and to promote efficiency and economy in Departmental operations." 39 In fiscal year 2015, OIG investigations resulted in 800 criminal actions against individuals or entities that engaged in crimes related to Medicare and Medicaid; 667 civil actions, which include false claims and unjust-enrichment lawsuits filed in federal district court, civil monetary penalties ("CMP") settlements, and administrative recoveries related to provider self-disclosure matters; and excluded 4,112 individuals and entities from participating in federal healthcare programs. ${ }^{40}$

Separate from the HHS, the $\mathrm{DOJ}^{41}$ opened 983 new criminal healthcare fraud investigations in $2015 .^{42}$ A total of 613 defendants were convicted of healthcare fraud-related crimes during the year and more than 144 health care fraud criminal enterprises were taken down. ${ }^{43}$ Also in 2015 , the DOJ opened 808 new civil healthcare fraud investigations and had 1,048 civil healthcare fraud matters pending at the end of the fiscal year. ${ }^{44}$ In the last seven years (through 2016), the DOJ has recovered a total of more than $\$ 30.9$ billion with more than $\$ 18.6$ billion of that amount recovered in cases involving fraud against federal health care programs. ${ }^{45}$

The government efforts to combat fraud and abuse within the healthcare industry are, no doubt, significant. However, the coordinated efforts among its various departments and agencies have not overcome the tremendous loss of federal funds. In implementing additional tools to combat fraud

${ }^{36}$ Jane Kim, Japanese and American Privacy Laws, Comparative Analysis, 32 J. MARSHALL J. INFO. TECH. \& PRIVACY L. 1 (2015).

${ }^{37}$ U.S. DEP'T OF JUSTICE, supra note 31, at 8; see also Improving Efforts to Combat Healthcare Fraud: Hearing Before the Comm. on Ways and Means, Subcomm. on Oversight, 112th Cong. (2011) (statement of Lewis Morris, Chief Counsel, Office of the Inspector General, Dep't of Health and Human Services).

${ }^{38}$ U.S. DEP'T OF JUSTICE, supra note 32, at 1.

39 The Effect of Exclusion from Participation in Federal Health Care Programs, OfFICE OF INSPECTOR GEN., https://oig.hhs.gov/exclusions/effects_of_exclusion.asp (last visited on Aug. 27, 2015).

${ }^{40}$ U.S. DEP'T OF JUSTICE, supra note 32.

${ }^{41}$ Act to Establish the Department of Justice, ch. 150, 16 Stat. 162 (1870) (providing the Department of Justice with control over federal law enforcement, all criminal prosecutions and civil suits in which the United States has an interest).

${ }^{4}$ U.S. DEP'T OF JUSTICE, supra note 32.

${ }^{43} \mathrm{Id}$.

${ }^{44}$ Id.

${ }^{45}$ Hospital Chain Will Pay over \$513 Million for Defrauding the United States and Making Illegal Payments in Exchange for Patient Referrals; Two Subsidiaries Agree to Plead Guilty, U.S. DEP'T OF JUSTICE (Oct. 3, 2016), https:/www.justice.gov/ [https://perma.cc/2BR7-CAUK] (last visited on Oct. 4, 2016) [hereinafter Hospital to pay $\$ 513$ Million]. 
and abuse in the healthcare industry, the government has increasingly relied on the RCOD to hold individuals responsible for the corporation's actions.

\section{The DeVElopment of THE RESPONSIBLE CORPORATE OFFICER DOCTRINE}

\section{A. Development of the Responsible Corporate Officer Doctrine}

The RCOD's roots can be traced to the 1922 Balint case, which involved an indictment of an individual for a violation of the Narcotic Act. ${ }^{46}$ The Balint Court stated: "[T]he State may in the maintenance of a public policy provide 'that he who shall do particular prohibited acts shall do them at his peril and will not be heard to plead in defense good faith or ignorance." "47 The Court further held that the strict liability practice was not a violation of due process, in large part because the importance of protecting the public health and safety outweighed the possible injustice of subjecting an innocent seller of narcotics to a penalty. ${ }^{48}$ This view and response to violations of due process allegations remain the law today.

Most commentary, however, holds the view that the RCOD first originated in 1943 as a criminal doctrine in the case of Dotterweich. ${ }^{49}$ Dotterweich involved a criminal prosecution of the corporate officers under the Federal Food, Drug, and Cosmetic Act ("FDCA") for shipping misbranded and adulterated drugs. ${ }^{50}$ In Dotterweich, the Supreme Court created the RCOD as a public welfare statute that was necessary to hold a corporate officer responsible for sharing in the furtherance of the transaction, which the statute outlaws. ${ }^{51}$

Thus, with the enactment of strict liability criminal provisions in public welfare and regulatory statutes, "the traditional basis for criminalizing conduct shifted from punishment of misbehavior to protection of the public from harm. This shift in emphasis has given rise to the 'responsible corporate officer' doctrine whereby a corporate official can be criminally responsible without proof of his knowledge of a violation." 52

Twenty-two years after Dotterweich, the RCOD was expanded from a criminal doctrine to apply in a civil context. This was done by the Supreme Court in the infamous 1975 case of United States v. Park. ${ }^{53}$ In Park, a corporate officer in the food chain industry was held liable under the RCOD,${ }^{54}$ the Court holding that "the defendant had, by reason of his position in the corporation, responsibility and authority either to prevent in the first instance, or promptly to correct, the violation complained of, and that he failed to do so." 55 The responsibility to promptly correct the

${ }^{46}$ Ronald M. Broudy, Rcra and the Responsible Corporate Officer Doctrine: Getting Tough on Corporate Offenders by Sidestepping the Mens Rea Requirement, 80 Ky. L.J. 1055, 1057 (1991); see also United States. v. Balint, 258 U.S. 250 (1922).

${ }^{47}$ Balint, 258 U.S. at 252 (1922).

${ }^{48}$ Id. at 254.

49 See Stillwater of Crown Point Homeowner's Ass'n, Inc. v. Kovich, 820 F.Supp.2d 859, 88990 (N.D. Ind. 2011) (stating that the first RCOD case was the Dotterweich case).

${ }^{50}$ United States v. Dotterweich, 320 U.S. 277, 278 (1943).

${ }^{51}$ Stillwater, 820 F.Supp.2d at 889 (N.D. Ind. 2011).

521 James D. COX \& ThOMAs LeE HaZEN, TREATISE ON THE LAW OF CORPORATIONS $\S 8: 22$ (3d ed. 2010).

${ }^{53}$ United States v. Park, 421 U.S. 658 (1975).

${ }^{54}$ Cox \& Hazen, supra note 52.

55 Park, 421 U.S. 658 at 673-74 (1975). 
issues complained of continues to find its emphasis in the compliance programs discussed in Part III of this paper.

At the time, the Solicitor General Robert H. Bork and attorneys from the DOJ presented to the Park court the following non-binding promise with regard to responsible corporate officials:

Even if investigation discloses the elements of liability, and indicates that an official bears a responsible relationship to them, the agency will not ordinarily recommend prosecution unless that official, after becoming aware of possible violations, often... as a result of notification by FDA, has failed to correct them or to change his managerial system so as to prevent further violations. ${ }^{56}$

Of note, according to the DOJ's statement above, at its inception, the RCOD placed emphasis on the elements of having knowledge and implementing corrective actions. Since 1975, however, the FDA has departed from the DOJ's view, particularly from the knowledge element of the RCOD, and advised:

The Park Doctrine ... provides that a responsible corporate official can be held liable for a first time misdemeanor ... under the [FDCA] without proof that the corporate official acted with intent or even negligence, and even if such corporate official did not have any actual knowledge of, or participation in, the specific offense. ${ }^{57}$

The responsible corporate officer doctrine has further developed and continues to apply to violations of public welfare statutes if a "statute is intended to improve the common good and [for which] the legislature eliminates the normal requirement for culpable intent, resulting in strict liability for all those who have a responsible share in the offense." 58

In balancing the public's interests against the demands and expectations placed on individual corporate officers, the courts consistently find that the interests of the general welfare ought to prevail: ${ }^{59}$ The requirements of foresight and vigilance imposed on responsible corporate agents are beyond question demanding, and perhaps onerous, but they are no more stringent than the public has a right to expect of those who voluntarily assume positions of

${ }^{56}$ Brief for the United States, at 31-32, U.S. v. Park, 421 U.S. 658 (1975) (No. 74-215) (emphasis added).

57 FDA Regulatory Procedures Manual, § 6-5-3- Special Procedures and Considerations for Park Doctrine Prosecutions, http://www.fda.gov/ [https://perma.cc/3794-K63B] (emphasis added).

58 Stillwater, 820 F. Supp. 2d at 893 (N.D. Ind. 2011).

${ }^{59}$ See United States v. Ne. Pharm. \& Chem. Co., 810 F.2d 726, $743-44$ (8th Cir. 1986); see also Matter of Dougherty, 482 N.W.2d 485, 489 (Minn. Ct. App. 1992); see also United States v. Harkonen, 510 Fed.Appx. 633 (9th Cir. 2013). 
authority in business enterprises whose services and products affect the health and well-being of the public that supports them. ${ }^{60}$

\section{B. Who is Responsible Under the Responsible Corporate Officer Doctrine and Who Else Should be Held Responsible?}

The OIG states that the RCOD may reach any managing employee. A "managing employee" is defined as an individual, including a general manager, a business manager, an administrator, or a director, who exercises operational or managerial control over the entity or who directly or indirectly conducts the day-to-day operations of the entity. ${ }^{61}$ In 2013, the FDA expanded how far the RCOD can reach to include third-party contractors (distributors) carrying responsibility for the actions of the manufacturers. ${ }^{62}$ Thus, the RCOD now appears to have a very wide reach indeed.

In order to establish a prima facie case in an action to hold a corporate director or officer personally liable for the corporation's wrongful conduct, the plaintiff, typically the government, must plead and prove the following elements:

(1) the individual must be in a position of responsibility which allows the person to influence corporate policies or activities; (2) there must be a nexus between the individual's position and the violation in question such that the individual could have influenced the corporate actions which constituted the violations; and (3) the individual's actions or inactions facilitated the violations. ${ }^{63}$

Of note, the terms "knowledge" and "intent" that are ubiquitous in criminal statutes are not among the elements of the RCOD. The prosecutors handling investigations acknowledge that the offense "requires no proof of intent or actual knowledge of the violations by the Corporate Officials to establish their guilt for the misdemeanor offense." ${ }^{64}$ Turning a blind eye is not an excuse under the RCOD either since passive management is not a permissible excuse. The RCOD is frequently referred to as a strict liability criminal doctrine, (up to one year in prison), which flies in the face of the customary criminal requirements for the defendants to have the mens rea (a specific state of mind to have an intent to carry out a criminal act). ${ }^{65}$

As it has developed, the RCOD holds corporate officers responsible for the wrongful actions of their corporations. If that, in fact, is the case then the government should be required to bootstrap RCOD charges with, at least misdemeanor, criminal charges against the wrongdoing corporations. Doing so would reinforce the proper targets of corporate wrongdoing within the maze of intertwined relationships of corporate officers, the Boards and corporations themselves. Further,

${ }^{60}$ Park, 421 U.S. at 672 (1975).

${ }^{61}$ Guidance for Implementing Permissive Exclusion Authority Under Section 1128(b)(15) of the Social Security Act, https://oig.hhs.gov/ [https://perma.cc/NAY7-J4E5] (hereinafter Guidance for Implementing Permissive Exclusion).

62 Douglas J. Behr et. Al., FDA Uses Warning LetTers to EXPAND the Park Doctrine tO InClude Violations OF CONTRACTORS, (2013), https://www.khlaw.com [https://perma.cc/J33L-7K29]

${ }^{63}$ People v. Roscoe, 169 Cal.App.4th 829, 839 (2008).

${ }^{64}$ Michael Friedman et. al. v. Sebelius et al., 2010 WL 251916112 (D.D.C. 2010).

${ }^{65}$ Clark, supra note 9, at 6. 
there would be legal safeguards to individuals in such situations, in that the corporate criminal charges would presumably contain standard elements of knowledge, intent, etc. which individual RCOD charges do not carry. If the government cannot prove beyond a reasonable doubt corporate wrongdoing, it should not be permitted to invoke RCOD as against corporate individuals. In other words, a responsible officer should not be criminally liable for the actions that, if viewed as the corporations' actions, are, in fact, not criminal. After all, isn't it what the RCOD is designed to do, to address corporate wrongdoing through individuals?

\section{Industries Most Affected by the Responsible Corporate Officer Doctrine}

The corporate officers most affected by the RCOD in the healthcare industry have been from pharmaceutical and medical device companies. Corporate officers in the healthcare provider sector have largely escaped personal liability unless the cases deal with $100 \%$ fraud and are prosecuted under the felony charges of the False Claims Act where typically a RCOD (a misdemeanor offense) has not been invoked. Healthcare providers should be wary, however, in that in addition to the typical triggers of the RCOD under the fraud and abuse laws, healthcare providers could also trigger the RCOD through HIPAA breaches, especially if it is found that IT security was too lax. ${ }^{66}$ The OIG has not held individuals responsible in any of the high-profile IT-related HIPAA breaches or hacks (yet) or in violations of the False Claims laws seeking misdemeanor convictions, even when violations appear egregious and could have been prevented or discovered sooner had they had an effective compliance program auditing and monitoring the organization's performance. ${ }^{67}$

The government may pursue corporate officers individually within the healthcare provider industry-as they have done in the pharmaceutical industry-if data breaches continue or the government does not think the industry is doing all it can to prevent or minimize those breaches. In fact, in the fall of 2016, OCR announced that it will investigate causes for breaches of fewer than 500 individuals and will pay attention to regions that do not report breaches as compared to other similarly situated covered entities. ${ }^{68}$ The Courts have already begun to analogize security breaches with a banana peel argument (viewing each IT breach as a fall on a banana peel) "were Wyndham a supermarket, leaving so many banana peels all over the place that 619,000 customers fall hardly suggests it should be immune from liability." 69

${ }^{66}$ Most recent and the largest HIPAA settlement, to date, of $\$ 5.5$ million has been inked by Advocate Health Care Network because its IT security was too lax and not reasonably safe. Jeff Overley, Ill. Hospital Chain Inks Record \$5.5M HIPAA Deal, LAw360, http://www.law360.com/ [http://perma.cc/CA2H-2XNA].

${ }^{67}$ Florida Hospital System Agrees to Pay the Government \$85 Million to Settle Allegations of Improper Financial Relationships with Referring Physicians, DEP'T OF JUSTICE (Mar. 11, 2014), http://www.justice.gov [http://perma.cc/ZAY7-VZX9]; Community Health Systems Inc. to Pay \$98.15 Million to Resolve False Claims Act Allegations, DEP’T OF JusticE (Aug. 4, 2014), http://www.justice.gov [http://perma.cc/SQH9-T895]; Data breach results in \$4.8 million HIPAA settlements, HHS.GOV (May 7, 2014), http://www.hhs.gov [http://perma.cc/NTN3-45FQ].

${ }^{68}$ OCR Announces Initiative to More Widely Investigate Breaches Affecting Fewer than 500 Individuals, HHS OFF. FOR C.R. IN ACTION, https://www.healthlawpolicymatters.com [http://perma.cc/H33Y-AJX2].

${ }^{69}$ F.T.C. v. Wyndham Worldwide Corp. et. al., 799 F.3d 236, 247 (3d Cir. 2015). 


\section{Defenses to Responsible Corporate Officer Doctrine}

One of the most potent and effective tools of the government in the prosecution of healthcare fraud and abuse cases are qui tam actions brought by the whistleblowers, who are typically employees of the corporation bringing to light the corporation's alleged violations of the federal laws. ${ }^{70}$ Should the government elect to intervene, and the plaintiff(s)/relators(s) ultimately prevail in qui tam actions, the relators are entitled to a statutory percentage of money damages recovered from the corporation. In September 2014, the DOJ announced that all new qui tams will be reviewed by the Criminal Division's corporate health care fraud strike force ${ }^{71}$ with the first such case concluding with a bang, recovering $\$ 513$ million against Tenet Healthcare Corporation. ${ }^{72} \mathrm{~A}$ shift from the initial presumption of a civil action to an automatic review for criminal prosecutions is quite threatening and troubling.

The challenge in such strict liability criminal cases is that the defendant cannot defend against the criminal allegations brought against him or her under the RCOD by asserting the standard lack of intent or lack of knowledge defenses, in that they are not the elements of the crime.

Asserting the usual garden variety of affirmative defenses is not effective. For instance, in the Halifax case, the hospital attempted to defend itself against the allegations of violations of the False Claims Act and the Stark Law brought by the government by asserting a number of affirmative defenses: failure to state a claim; estoppel; waiver; good faith; limitations on damages; fraud with particularity; public disclosure; and exceptions to the Stark Law. ${ }^{73}$ The Court correctly noted that several of those defenses (failure to state a claim upon which relief may be granted; failure to plead fraud with particularity; estoppel and waiver) are not even available as a matter of law. ${ }^{74}$ Further, the public disclosure affirmative defense is a bar to an FCA claim brought by a relator, ${ }^{75}$ but not to an FCA claim asserted by the United States. ${ }^{76}$ The remaining affirmative defenses were found to be moot or inapplicable on other grounds. ${ }^{77}$ None of the "standard" affirmative defenses are effective in suits brought by the government, in that they simply dilute the strength of a legitimate defense, if there was any in the first place. Though the defendant in the

7031 U.S.C $\$ 3730($ b)(1) (2010).

${ }^{71}$ Scott R. Grubman, Top Ten Health Law Issues, Fraud and Abuse Enforcement, 19 AHLA CONNECTIONS (Feb. 2015) 14, http://cclblawyers.com/ [https://perma.cc/CD56-9MU3].

72 Hospital to pay $\$ 513$ Million, supra note 45 . In contrast to the government's rhetoric, consider this: the latest healthcare fraud settlement with Tenet Healthcare is not its first and Tenet Healthcare is a repeat offender with the government. Its CEO Trevor Fetter has been in his position with the company since 2003 during most of Tenet's fraud cases, yet the government has not held Mr. Fetter, or anyone else in the position of a responsible corporate officer, individually accountable. See Allison Watts, Medicare Thief? Tenet Strikes Again: Serial Offender Offers \$513M FCA Settlement, Whistleblower News Rev. (Aug. 2016), http://www.whistleblowergov.org [https://perma.cc/QZM9-444W].

${ }^{73}$ United States v. Halifax Hosp. Med. Ctr., No. 6:09-CV-1002-ORL-31, 2013 WL 6017329, at $* 1, * 12$ (M.D. Fla. Nov. 13, 2013).

${ }^{74}$ Id.

7531 U.S.C. $\S 3730$ (2016).

${ }^{76}$ Halifax Hosp. Med. Ctr., 2013 WL 6017329, at*12 (Nov. 13, 2013); see also, 31 U.S.C. $\S$ 3730(e)(4) (2016).

${ }^{77}$ Halifax Hosp. Med. Ctr., 2013 WL 6017329, at*13 (Nov. 13, 2013). 
Halifax case was a hospital, rather than an individual corporate officer, one can see that the assertion of similar affirmative defenses by an individual defendant under a RCOD prosecution would likely have the same results.

Certainly, the defendant may assert, if available under the facts of the case, (a) that s/he was not in the position of responsibility at the time the alleged improper acts occurred; (b) that there is no nexus between his/her position and the violation in question, in that s/he could not have influenced the corporate actions which constituted the violations; and/or (c) that whatever actions or inactions $\mathrm{s} /$ he chose to undertake they did not facilitate the violations. There is typically no occasion to invoke such defenses however, since had these been viable defenses available to the individual, the government would unlikely have charged such individual under the RCOD in the first place.

One affirmative defense that may be available to individual defendants under a RCOD prosecution, however, is if "a defendant was 'powerless' to prevent or correct the violation."78 The first case to recognize the "powerless" defense in the RCOD context involved the FDA criminally charging a warehouseman for storing food in "unsanitary conditions in a building accessible to rodents, birds and insects, where the [food] may have become contaminated with filth."79 The Court stated that in cases involving violations of public welfare laws that protect "the lives and health of human beings" the FDA may bring an action against a third party intermediary corporation, including its warehouseman, who did not sell but merely stored food that was placed in interstate commerce. ${ }^{80}$ The Court recognized, however, that the warehouseman may defend against such alleged violation invoking the "powerless" defense, further taking the position that the warehouseman was powerless "to protect against this kind of contamination, however high the standard of care [he may have] exercised." 81 Since such defense involved a question of fact, the case was remanded to lower court for further proceedings. ${ }^{82}$

In the modern context, prosecutors may easily overcome a "powerless" defense, however, in that the responsible corporate officer likely had the power to "prevent or correct" the prohibited acts, otherwise they would not be a "responsible" corporate officer for the wrongful acts in question. There is an issue here if the corporate officer did not have to have knowledge about the prohibited acts, and thus was unable to exercise his or her power to correct the violation. In such regard, courts have noted that, "[m]erely because a person is an officer or agent of the corporation [charged with misbranding a product introduced into interstate commerce] does not mean per se that he automatically stands in a position of criminal liability." ${ }^{83}$ Likewise, if during the audit a violation or a breach was not detected, it does not automatically mean that someone is personally criminally responsible. ${ }^{84}$ This lack of knowledge, and whether such knowledge is properly

${ }^{78}$ United States v. Park, 95 S.Ct. 1903, 1912 (1975); quoting United States v. Wiesenfeld Warehouse Co., 376 U.S. 86, 91 (1964).

${ }^{79}$ Wiesenfeld, 376 U.S. at 87 (1964).

${ }^{80} \mathrm{Id}$. at 91.

${ }^{81} \mathrm{Id}$.

${ }^{82}$ Id. at 92 .

${ }^{83}$ United States v. 48 Jars, More or Less, of an Article of Drug Labeled Tranquilease, 23 F.R.D. 192, 195 (D.D.C 1958).

${ }^{84}$ U.S. Sentencing Guidelines Manual $§$ 8B2.1(a)(2) (U.S. Sentencing ComM’n 2014). 
attributable to the individual corporate official, does cut against the strict liability manner of convictions.

The strongest defense or prophylactic measures to prosecution of individuals under the RCOD is to establish and maintain a robust and effective compliance program implemented by the corporation from the top down. Compliance programs that are embraced by an entire organization to the extent that they become a part of the organization's culture are likely to prevent prosecution under the RCOD, whether it is the DOJ, OIG, OCR, or FDA who is reviewing the violation. ${ }^{85}$ (Part Three of this paper focuses on compliance programs.) On the other hand, if the compliance program is weak and anemic, and had a more robust program been implemented so as to have detected and prevented the violation; or, considering another variation, if the compliance program is robust but the response to a discovered issue is inadequate, then under such circumstances individual corporate officers have a reason for concern. There is no legal defense or affirmative defense under such circumstances that would suffice.

Therefore, in addition to fines, penalties and the like, the government's solution to violations of healthcare fraud and abuse laws are compliance programs, as evidenced by the government's imposition of the Corporate Integrity Agreements ("CIA") that essentially operate as governmentimposed-and-monitored compliance programs. ${ }^{86}$

85 See OIG ET AL., Practical Guidance for Health Care Governing Boards on Compliance Oversight, 1, 6 (Apr. 20, 2015), https://oig.hhs.gov/ [https://perma.cc/3MKN-DR7T] [hereinafter PRACTICAL GUIDANCE] ("The compliance function promotes the prevention, detection, and resolution of actions that do not conform to legal, policy, or business standards. This responsibility includes the obligation to develop policies and procedures that provide employees guidance, the creation of incentives to promote employee compliance, the development of plans to improve or sustain compliance, the development of metrics to measure execution (particularly by management) of the program and implementation of corrective actions, and the development of reports and dashboards that help management and the Board evaluate the effectiveness of the program.") Id. at 6.

$86 \mathrm{OIG}$, Corporate Integrity Agreements, http://oig.hhs.gov [https://perma.cc/2LJ9-HCLA] (last visited Oct. 27, 2016) ("CIAs have many common elements, but each one addresses the specific facts at issue and often attempts to accommodate and recognize many of the elements of preexisting voluntary compliance programs. A comprehensive CIA typically lasts 5 years and includes requirements to:

- hire a compliance officer/appoint a compliance committee;

- develop written standards and policies;

- implement a comprehensive employee training program;

- retain an independent review organization to conduct annual reviews;

- establish a confidential disclosure program;

- restrict employment of ineligible persons;

- report overpayments, reportable events, and ongoing investigations/legal proceedings; and

- provide an implementation report and annual reports to OIG on the status of the entity's compliance activities."). 


\section{E. Civil Remedies of Exclusion}

\section{Exclusions of Individuals by the OIG}

The OIG turned to civil remedies of exclusion from receiving reimbursement from federal health programs ${ }^{87}$ primarily to address issues of fraud and abuse within large healthcare organizations. Congress first gave the Secretary of HHS the authority to exclude individuals from participation in federal healthcare programs in 1977, and HHS delegated this authority to OIG in 1981. Over the past 30 years, the OIG has used this authority to exclude individuals who commit fraud under federal health programs. ${ }^{88}$

In 2010, OIG excluded 3,340 individuals and entities under its permissive authority ${ }^{89}$ In 2015 , this number has risen to 4,112 individuals and entities excluded from participation in Medicare, Medicaid, and other federal healthcare programs. ${ }^{90}$

In evaluating prosecutions, government prosecutors are to consider whether the facts and circumstances support criminal investigation and possible prosecution. In particular, among other factors, we look at the severity or pervasiveness of any compliance failures, the involvement and culpability of individuals, and the availability and appropriateness of regulatory or civil enforcement action, as opposed to criminal prosecution. ${ }^{91}$

There are vastly different bases to seek exclusion of individuals depending on whether the individual has an ownership interest in the corporation or $\mathrm{s} / \mathrm{he}$ is a managing employee of the corporation. "Individuals who have an ownership or a control interest in a sanctioned entity may be excluded under section 1128(b)(15)(A)(i) if they knew or should have known of the conduct

87 Health Law Resources, AMERICAN HeAlth LAWYers AsSOCIATION, https://www.healthlawyers.org [https://perma.cc/RLW8-LKWJ] (last visited Oct. 27, 2016) ("There is no explicit list maintained by OIG of what programs it considers to meet this definition, instead choosing to let the words speak for themselves."); Many of the federal healthcare programs are codified under 42 U.S.C. $\S 14402$ (2016).

${ }^{88}$ Jason M. Crawford, A Bitter Pill for the Pharmaceutical Industry? Hhs-Oig's Enforcement of the Responsible Corporate Officer Doctrine, 17 QuinNIPIAC HEALTH L.J. 45, 46 (2014).

${ }^{89}$ Tom Herrmann, The New OIG "Responsible Corporate Officer Doctrine", J. OF HeAlTH CARE COMPLIANCE (Jan. - Feb. 2011), http://compliance.com [https://perma.cc/QQN3-7S6R].

${ }^{90}$ U.S. DEP'T OF Justice, supra note 32. (“Among these were exclusions based on criminal convictions for crimes related to Medicare and Medicaid $(1,329)$ or to other health care programs (424); for patient abuse or neglect (302); or as a result of licensure revocations (1743).”)

91 Asst. Att'y Gen. Leslie R. Caldwell, Remarks at the American Bar Association's 25th Annual National Institute on Healthcare Fraud, United States Dep'T of Justice, (May 14, 2015), http://www.justice.gov/ [https://perma.cc/QTC4-E329] (last visited August 11, 2015). 
that led to the sanction." 92 Given this high burden of proof, only six exclusions were imposed under the ownership Section in 2010. ${ }^{33}$ By contrast, "officers and managing employees, as defined in section 1126(b) of the Social Security Act, may be excluded under section 1128(b)(15)(A)(ii) based solely on their position within the entity." 94

Because the elements of these two provisions are so different, [OIG's] exclusion analysis differs depending on whether the individual in question is:

(1) an owner or (2) an officer or a managing employee ... [t]hese factors were derived from multiple sources, including: (1) the regulations governing exclusions under sections $1128(\mathrm{~b})(15)$ and $1128 \mathrm{~A}$ of the Act; [ ] (2) the factors for implementation of permissive exclusion under section $1128(\mathrm{~b})(7){ }^{95}$ [] (3) the responsible corporate official doctrine established in case law, including U.S. v. Park, [ ]; and (4) decisions of the Departmental Appeals Board in exclusion matters. ${ }^{96}$

The government provides extensive guidance with the goal that the corporations and responsible individuals are well-equipped to comply with its programs. The OIG provides very comprehensive Guidance for Implementing Permissive Exclusion Authority Under Section 1128(b)(15) of the Social Security Act. For instance:
A. Circumstances of the Misconduct and Seriousness of the
B. Individual's Role in Sanctioned Entity
C. Individual's Actions in Response to the Misconduct Information About the Entity .... ${ }^{97}$

The first case to exclude an individual under Section 1128(b)(15) was in 2010, when the OIG excluded Marc Hermelin, top executive of the K-V Pharmaceutical Company, of which he was also a major shareholder. ${ }^{98} \mathrm{Mr}$. Hermelin pleaded guilty to criminal charges, the basis for his exclusion. ${ }^{99}$ OIG stated that if he failed to resign from his position and withdraw from company ownership that the company would be excluded, too. ${ }^{100}$ The OIG stated that:

Although an exclusion does not directly prohibit the excluded person from owning a provider that participates in Federal health care programs, there are several risks to such ownership. The OIG

\footnotetext{
92 Guidance for Implementing Permissive Exclusion, supra note 61.

${ }^{93}$ Herrmann, supra note 89.

94 Guidance for Implementing Permissive Exclusion, supra note 61.

${ }^{95}$ Quoting, 62 Fed. Reg. 67392 (Dec. 17, 1997).

${ }^{96}$ Guidance for Implementing Permissive Exclusion, supra note 61.

${ }^{97} \mathrm{Id}$.

${ }^{98}$ Herrmann, supra note 89, at 50.

${ }^{99} \mathrm{Id}$.

${ }^{100}$ Id.
} 
may exclude the provider if certain circumstances regarding the ownership are present. [A]ny provider owned in part (5 percent or more) by an excluded person is potentially subject to exclusion. ${ }^{101}$

With this statement made in 2013 OIG expanded its focus of discretionary exclusion authority to healthcare providers. ${ }^{102}$

When the OIG considers excluding an individual or entity under Section 1128 of the Social Security Act, ${ }^{103}$ it sends out a written Notice of Intent to Exclude ("the Notice") to the affected individual. ${ }^{104}$ The individual then has thirty days to respond in writing and must include any relevant issues or mitigating factors therein. ${ }^{105}$ In one such instance, a corporate officer, individually, was successful in responding to such Notice of Exclusion and, ultimately, was not excluded. ${ }^{106}$

101 OIG, Special Advisory Bulletin on the Effect of Exclusion from Participation in Federal Healthcare Programs, (May 8, 2013), http://oig.hhs.gov [https://perma.cc/B5HW-YRF3] (internal citation omitted).

102 The Purdue and OxyContin case, that excluded three corporate officers from federal program participation for twenty years (later reduced to less than twelve years), sent ripples through the health industry; see discussion infra Part IV.

103 Exclusions FAQ, Off. of InsPector Gen.: U.S. DeP'T of Health \& Human Servi., http://oig.hhs.gov/ [https://perma.cc/YHH9-4UBZ] (follow "What is OIG's administrative process for imposing Exclusions?" hyperlink; then look under "Details" in that section). (last visited Nov. $11,2016)$

The administrative process [for exclusions] is governed by regulations codified at 42 C.F.R. sections 1001.2001 through $1001.2007 \ldots$ For all proposed mandatory exclusions $(\S \S 1128(\mathrm{a})(1)-$ (4) of the Act) that are longer than the mandatory minimum fiveyear period, and most proposed permissive exclusions $(\S \S 1128(b)(1)-(b)(5), \quad(b)(8)-(b)(11), \quad$ and $(b)(14)-(b)(15)$, and (b)(16) of the Act), the administrative process is the same.

${ }^{104}$ Id.

${ }^{105} \mathrm{Id}$.

${ }^{106}$ Press Release, U.S. Dep’t of Justice, Drug Maker Forest Pleads Guilty; To Pay More Than \$313 Million to Resolve Criminal Charges and False Claims Act Allegations (September 15, 2010), http://www.justice.gov/ [https://perma.cc/6CWL-6EHA]. Howard Solomon, CEO of Forest Laboratories was successful in responding to such a Notice from the OIG. Id. The OIG's Notice followed the company's voluntary guilty plea “to charges relating to obstruction of justice, the distribution of Levothroid, which at the time was an unapproved new drug, and the illegal promotion of Celexa for use in treating children and adolescents suffering from depression," further incorporating False Claims Act allegations. Id. Forest Laboratories paid more than \$313 million to resolve criminal and civil liabilities. Solomon responded to the exclusion action and just four months thereafter, on August 5, 2011, the OIG informed Solomon that "[b]ased on a review of the information in our file and consideration of the information that your attorneys provided to us, both in writing and during an in-person meeting, we have decided to close this case." Crawford, supra note 12, at 54. Further explanation as to what information may have led them to drop the 


\section{Exclusion of Entities by DOJ}

Although an entity and an individual may be excluded, if the government were to exclude a publicly traded company that provides services or medical devices and benefits to many beneficiaries, it may hurt the entire industry. Logically, if the DOJ were to exclude individuals running those entities, then perhaps it would influence the future behavior of officers and encourage compliance with federal program requirements. ${ }^{107}$ Likewise, since organizations operate through people, it is people that should be punished, and not the organizations themselves. In theory, by holding individual corporate officers responsible and excluding the "bad" individuals, the government will return the organization to where it should be. ${ }^{108}$

In considering whether to exclude a corporation from participation in federal programs, the DOJ instructed that:

[T] he prosecutor must weigh all of the factors normally considered in the sound exercise of prosecutorial judgment: . . . However, due to the nature of the corporate "person," some additional factors are present. [Therefore] ... prosecutors should consider the following factors in reaching a decision as to the proper treatment of a corporate target: the nature and seriousness of the offense ...; the pervasiveness of wrongdoing within the corporation ... ; the corporation's history of similar misconduct . . .; the corporation's timely and voluntary disclosure of wrongdoing and its willingness to cooperate in the investigation of its agents ...; the existence and effectiveness of the corporation's pre-existing compliance program ... ; the corporation's remedial actions. . .; collateral consequences ...; the adequacy of the prosecution of individuals responsible for the corporation's malfeasance; and the adequacy of remedies such as civil or regulatory enforcement actions. ... ${ }^{109}$

Further, the DOJ emphasized that only a corporation's genuine cooperation that provides full and complete disclosure of culpable individuals is acceptable. ${ }^{110}$ As evidenced by a DOJ press release stating that corporations should be mindful of feigning cooperation, in that voluntary

charges was provided but it is likely he had effectively addressed all the elements of the OIG's Guidance for Implementing Permissive Exclusion Authority.

${ }^{107}$ Videotape: Professor Singer on Tax-Exempt Organizations (on file with author at Loyola University Chicago School of Law (2015)).

${ }^{108} \mathrm{Id}$.

${ }^{109}$ Memorandum from Mark Filip, Deputy Attorney Gen., U.S. Dept. of Justice, to Heads of Dep't Components, U.S. Attorneys, Principles of Federal Prosecution of Business Organizations, Attachment 3, 4, (Aug. 28, 2008), http://www.justice.gov [https://perma.cc/ARQ3-X5AY] [hereinafter Filip Memo].

${ }^{110}$ Press Release, U.S. Dep't of Justice, Deputy Assistant Attorney General Sung-Hee Suh Speaks at the PLI's 14th Annual Institute on Securities Regulation in Europe: Implications for U.S. Law on EU Practice, (January 20, 2015), http://www.justice.gov/ [https://perma.cc/RZF7C9NP] [hereinafter Implications for U.S. Law on EU Practice]. 
disclosure of culpable individuals without timely and full supporting evidence of their criminal conduct is not acceptable cooperation. ${ }^{111}$ In continued effort to engage corporations in cooperation with the DOJ, it now added a separate the "Filip factors," which emphasizes meaningful incentives for self-disclosure before the DOJ becomes aware of any wrongdoing. ${ }^{112}$

Although the above statement was expressed within the securities industry context, as recently as 2015, the DOJ reiterated that it prioritizes "the fight against financial fraud of all stripesparticularly at publicly traded corporations and large financial institutions ... [ $\mathrm{t}$ ] he prosecution of individuals - including corporate executives - for criminal wrongdoing continues to be a high priority for the department." 113

Accordingly, relationships between corporations and its corporate officers are intertwined, and both are responsible for corporate wrongdoing. For individuals, however, the most effective protection against wrongdoing is a robust and effective compliance program. If such proactive measures have not been implemented in the foreground, individuals may find themselves ultimately paying with their careers while their respective corporations pay a fine and move on. Such an outcome is outlined in the Purdue Frederick Company ("Purdue") case discussed below.

\section{PURDUE AND OXYCONTIN}

The Purdue and its OxyContin cases garnered much publicity, in that Purdue's corporate officers were excluded from federal health programs for many years, which essentially ended their careers. ${ }^{114}$ It is a bit surprising why so many were shocked by the severity of the punishment and the effect on the individuals' careers. The outcome of the case was not untoward, however. Further, as this section examines the crime and its consequences, it offers suggestions that could have prevented the problems from occurring, or at least reduced the severity of the punishment.

Purdue was convicted of felony misbranding with intent to defraud in violation of FDCA. ${ }^{115}$ Michael Friedman, Paul Goldenheim and Howard Udell ("the Trio") "were senior corporate officers" at Purdue, at the time when it was "involved [in] misbranding the painkiller OxyContin." "116 Simultaneously with Purdue's guilty plea, the Trio pleaded guilty to misdemeanors relating to fraud or the unlawful distribution of controlled substances in violation of 21 U.S.C. $\S$ 331(a) and $\S 333(\mathrm{a})(1)$, "for their admitted failure to prevent Purdue's fraudulent marketing of OxyContin." "117 Fraudulent marketing of OxyContin involved certain sales personnel marketing

${ }^{111} I d$.

112 Deputy Attorney General Sally Q. Yates Delivers Remarks at the 33rd Annual International Conference on Foreign Corrupt Practices Act (December 2, 2016), https://www.justice.gov/ [https://perma.cc/KR3Y-BWK9].

${ }^{113}$ Implications for U.S. Law on EU Practice, supra note 110. (emphasis added).

${ }^{114}$ United States v. Purdue Frederick Co., 495 F. Supp. 2d 569 (W.D.Va. 2007); Friedman v. Sebelius, 755 F. Supp. 2d 98, 102 (D.D.C. 2010) rev'd, 686 F.3d 813 (D.C. Cir. 2012).

11521 U.S.C. § 331(a) and § 333(a)(2).

116 Thomas Sullivan, Friedman vs. Sebelius: Purdue Executive Exclusion Upheld, but Terms Voided as Arbitrary and Capricious, PolicyMed (Aug. 8, 2012, 5:08 AM), http://www.policymed.comhtml [https://perma.cc/5QQN-7SHQ]. Some sales personnel were found to promote the drug contrary to the FDA label's warning.

${ }^{117}$ Friedman v. Sebelius, 686 F.3d 813, 816 (D.C. Cir. 2012). 
the drug contrary to its label, thus contributing to diversion of the drug for illicit use. ${ }^{118}$

Purdue agreed to accept a guilty plea, be placed on probation for five years and pay $\$ 600,000$ in fines and other monetary sanctions. ${ }^{119}$ Each member of the Trio "was sentenced to 400 hours of community service, fined $\$ 5,000$, and put on probation for three years." "120 The sentencing court also ordered the Trio "to disgorge compensation they had received from Purdue totaling approximately $\$ 34.5$ million."121 Most harmful to the Trio was the order to exclude the individuals from participating in federal health programs for twenty years, which was later reduced to twelve years. ${ }^{122}$ The twelve-year-exclusionary period was overturned on appeal as excessive, and the record does not indicate the ultimate number of years of exclusion. ${ }^{123}$

\section{A. OxyContin}

The Trio recognized the danger of OxyContin and admitted as such in one of their motions to the court describing OxyContin as a Schedule II controlled substance with a twelve-hour-release, opioid analgesic. ${ }^{124}$ The FDA approved OxyContin "in 1995 to treat moderate to severe pain when an around-the-clock analgesic is needed for an extended period of time."125 The original FDAapproved OxyContin label stated that the "[d]elayed absorption, as provided by OxyContin tablets, is believed to reduce the abuse liability of a drug." The label further warned that, "[t]ablets are to be swallowed whole, and are not to be broken, chewed or crushed. Taking broken, chewed or crushed OxyContin tablets could lead to the rapid release and absorption of a potentially toxic dose of oxycodone." 126

The Trio went on to state that by definition, all Schedule II controlled substances are highly subject to abuse, further acknowledging that, "[i]n 2000, reports began emerging that OxyContin was [in fact] being abused, despite the clear warning in its FDA-approved label."127 "[A]ddicts soon discovered that crushing the pills defeated the time-release system. They could then snort or inject the drug for an intense, immediate high." 128 The Trio reported to the court that, "[a]ccording to federal government studies, almost $100 \%$ of individuals who abuse OxyContin had previously

118 U.S. Gen. Accounting OfFICE, GAO-04-110, Prescription Drugs: OXyContin Abuse AND Diversion AND EFForts tO AdDress the Problem (January 22, 2004), http://www.gao.gov/htext/d04110.html [https://perma.cc/R3EW-Z7QR ].

${ }^{119}$ Sebelius, 686 F.3d at 816.

${ }^{120} \mathrm{Id}$.

${ }^{121} \mathrm{Id}$.

${ }^{122}$ Id. at 817.

${ }^{123} \mathrm{Id}$. at $828,813-32$.

${ }^{124}$ Memorandum of Points and Authorities in Support of Plaintiffs' Motion for Summary Judgment at 6, Friedman v. Sebelius, 755 F. Supp. 2 d 98 (D.D.C. 2010), rev'd, 686 F.3d 813 (D.C. Cir. 2012) (No. 1:09-cv-02028-ESH), 2010 WL 2519161 [hereinafter Memorandum for Plaintiffs' Motion for Summary Judgment].

${ }^{125} \mathrm{Id}$.

${ }^{126} \mathrm{Id}$.

${ }^{127}$ Id. at 7.

128 David Armstrong, Purdue Says Kentucky Suit Over OxyContin Could Be Painful BloOMBerg Bus. (Oct. 19, 2014, 12:01 AM), http://www.bloomberg.com [https://perma.cc/R9BQ-E3ME]. 
used illegal drugs (including cocaine and heroin) or had engaged in non-medical use of other prescription drugs." 129 The Trio was possibly attempting to infer that they were "powerless" in preventing known drug-addicts from abusing OxyContin.

\section{B. Sales Personnel, Misbranding and Inadequate Compliance Program}

Under the FDCA, misbranding, as it relates to the promotion or advertising of a drug, occurs when a manufacturer or distributor makes statements about a drug that are false or misleading or that fail to meet the FDCA's requirements for a "true statement of information"-which is, in essence, any departure from the drug's FDA-approved labeling. ${ }^{130}$

The Trio was convicted despite clear and appropriate FDA warnings on the OxyContin label because "certain" Purdue's sales employees "deviated from the FDA-approved label and described OxyContin as less addictive, less subject to abuse and diversion, and less likely to cause withdrawal and tolerance than immediate-release opioid medications," whereby such misstatements constituted misbranding. ${ }^{131}$ The Trio argued that since "only two-tenths of one percent-1 in 500-of the call notes of Purdue sales representatives evidence any potential misstatement," 132 it should not be sufficient to convict Purdue's responsible corporate officers individually. ${ }^{133}$

The federal sentencing guidelines for corporations specifically state:

An organization that, due to the nature of its business, employs sales personnel who have flexibility to represent the material characteristics of a product shall establish standards and procedures designed to prevent and detect fraud .... The failure to prevent or detect the instant offense does not necessarily mean that the program is not generally effective in preventing and detecting criminal conduct.

[Rather, the government focuses on t] he prior diligence of an organization in seeking to prevent and detect criminal conduct [which] has a direct bearing on the appropriate penalties and probation terms for the organization ...."134

Therefore, it is more likely than not that had Purdue maintained an effective compliance program for its sales personnel, a few "bad apples" within the sales force would not have dragged

${ }^{129}$ Memorandum for Plaintiffs' Motion for Summary Judgment, supra note 124, at 8. (internal citation omitted).

${ }^{130}$ Id. at 9; see 21 U.S.C.A. $\S \S 352(\mathrm{a}), 352(\mathrm{n})$ (Westlaw through Pub. L. No. 114-229); 21 C.F.R. $\S \S 202.1(\mathrm{a})-(\mathrm{b}),(\mathrm{e})(2008)$.

131 Memorandum for Plaintiffs' Motion for Summary Judgment, supra note 124, at 9-10. (internal citation omitted).

${ }^{132} \mathrm{Id}$. at 10. (internal citation omitted).

${ }^{133} \mathrm{Id}$. at 31.

134 U.S. Sentencing Guidelines Manual § 8B2.1 at 512, 517 (U.S. SENTENCING ComM’N 2011), http://www.ussc.gov/ [https://perma.cc/N6BW-FZVM]. 
the entire company and its RCOs into criminal convictions and exclusions. An effective compliance program would have either prevented improper conduct through proper training of Purdue's sales force or detected and timely remedied an improper conduct through regular monitoring and auditing functions.

\section{The Trio's Defenses}

The Trio argued that they were not convicted of fraud, and therefore, never formed intent to defraud; and, that they should not be held responsible for the conduct of "others" (an entity for which they were senior executive officers), and therefore exclusion should not apply. ${ }^{135}$ They further argued that, "misstatements that constituted misbranding during a limited number of sales calls," do not rise to the level of "any negligent acts in performance of their duties, nor that they were aware of unlawful acts by others." 136 The "limited number of sales" referenced by the Trio, in reality, was into multi-million-dollars. ${ }^{137}$

While in court documents, Purdue asserted ignorance of any impropriety as its defense, Purdue was battling more than 400 personal-injury lawsuits related to the drug throughout the country. ${ }^{138}$ Kentucky Attorney General Jack Conway said that the wave of addiction led to misery and crime and that he wants, "to hold them accountable in eastern Kentucky for what they did," further adding that the wave of addiction led to misery and crime resulting in the loss of "an entire generation. Half the pharmacies in Pike County have bulletproof glass. We had FedEx trucks being knocked off. It was the Wild West." 139 Purdue and its responsible officers could not have been ignorant of the accusations mounting against it.

During the time Purdue was succeeding on their Motions to Dismiss in various states, the government was conducting a multi-year investigation of Purdue, which culminated in criminal convictions.

\section{Others Involved in the OxyContin and the Illicit Drug Scandal}

Purdue was not the only corporation involved in the OxyContin scandal, but it was the only one to have its corporate officers bear individual responsibility for the company's acts. At around the same time as the Purdue investigation, in the countrywide sweep of companies, "[the] DEA initiated 257 OxyContin-related abuse and diversion cases in fiscal years 2001 and 2002, which resulted in 302 arrests and about $\$ 1$ million in fines." ${ }^{140}$ Further, the DEA indicted UPS and FedEx

${ }^{135}$ Memorandum for Plaintiffs' Motion for Summary Judgment supra note 124, at 2.

${ }^{136} \mathrm{Id}$. at 12 (Of note, the Trio's legal defenses hereto relate to the sentencing phase of the case. It appears that during the trial's sentencing phase, the Trio conflated elements of negligence and knowledge as their defensive legal positions, none of which are proper defenses under the RCOD. The Trio did not have an occasion to assert legal defenses to the Complaint, in that they pled guilty following the filing of the Complaint).

${ }^{137}$ Memorandum for Plaintiffs' Motion for Summary Judgment, supra note 124. ("Due to the increased prescriptions, annual sales rose from \$44 million in 1996 to \$1.3 billion in 2001.”).

${ }^{138}$ Armstrong, supra note 128.

${ }^{139} \mathrm{Id}$.

${ }^{140}$ U.S. GEN. ACCOUNTING OFFICE, supra note 118. 
Corporation for diverting OxyContin and other illicit drugs on behalf of illegal online pharmacies, ${ }^{141}$ and Walgreens was fined $\$ 80$ million for diverting illicit drugs to black markets. ${ }^{142}$

Cardinal Health shipped OxyContin in such staggering quantities that in one Florida town of Sanford with population of 53,000, Cardinal Health's supply of OxyContin could support $400,000 .{ }^{143}$ The DEA alleged that distributors of Schedule II drugs with a "high potential for abuse" 144 must maintain "effective control against diversion of particular controlled substances into other than legitimate medical, scientific, and industrial channels." ${ }^{145}$ In addition, "distributors that supply controlled substances to pharmacies must 'design and operate a system to disclose to the [distributor] suspicious orders of controlled substances' and, in turn, disclose those suspicious orders to the DEA."146 "Suspicious orders include orders of unusual size, orders deviating substantially from a normal pattern, and orders of unusual frequency."147

"[T] he DEA repeatedly notified Cardinal [Health] of its need to exercise greater diligence at the Lakeland Facility to detect suspicious activity by its customers."148 And the DEA has taken enforcement actions against Cardinal Health, including its Lakeland Facility. ${ }^{149}$ Despite prior enforcements, Cardinal Health continued to distribute OxyContin to two CVS pharmacies in staggering quantities, and individual corporate officers were not charged with any crime. ${ }^{150}$

\section{E. The Trio's Plea Deal}

Once the DOJ investigates and finds violations, then it is commonly accepted that a plea agreement is forthcoming, in that, "a conviction at trial ... put [s] the individual in a position almost certainly no better (and probably worse) than if s/he had pleaded guilty to the RCO [Responsible Corporate Officer] misdemeanor ....."151

${ }^{141}$ Press Release, U.S. Dep't of Justice, FedEx Indicted for Its Role in Distributing Controlled Substances and Prescription Drugs (July 17, 2014) http://www.fda.gov/ [https://perma.cc/WW94YH4K]; Press Release, U.S. Dep't of Justice, UPS Agrees to Forfeit $\$ 40$ Million in Payments from Illicit Online Pharmacies for Shipping Services (March 29, 2013) http://www.fda.gov [https://perma.cc/7YJ8-9X9T].

142 Erin Marie Daly, FedEx Faces Drug-Trafficking Charges, OXY WATCHDOG (July 20, 2014), http://oxywatchdog.com/ [https://perma.cc/QM3G-8VPP].

143 Tom Schoenberg, Cardinal Health Blocked from Shipping Painkiller in Florida, (2012), http://www.bloomberg.com/news/articles/2012-02-29/cardinal-health-blocked-from-shippingpainkiller-in-florida-1-.

14421 U.S.C. $\$ 812(\mathrm{~b})(2)(\mathrm{A})(2012)$.

${ }^{145}$ Cardinal Health, Inc. v. Holder, 846 F. Supp. 2d 203, 206 (D.D.C. 2012) (citing 21 U.S.C. $\S 812(\mathrm{~b})(1)(2012))$.

${ }^{146}$ Id. (citing 21 C.F.R. $\left.\S 1301.74(\mathrm{~b})\right)$.

${ }^{147}$ Id. at 206-07.

${ }^{148}$ Id. at 208.

${ }^{149}$ Id. at 207.

${ }^{150} \mathrm{Id}$.

151 Clark, supra note 9, at 5 (citing Gregory L. Poe, The Responsible Corporate Officer Doctrine: Defending Individuals in FDCA Cases, 21 st ANN. NAT'L INST. ON HEALTH CARE FRAUD D-5 (April 2011)). 
Consequently, it was not surprising that the Trio accepted guilty pleas. What was surprising, however, was when these particular guilty pleas, accepted voluntarily, resulting in the corporate officers' exclusion from participating in federally funded Medicare/Medicaid programs, many corporate officers, lawyers, interested academics and reporters sharing similar mind-sets on the matter, expressed either outrage or fear of the government agencies' overreaching. ${ }^{152}$

More often than not, however, guilty pleas do result in people losing their employment, professional licenses, deportation, and may culminate in losing the support of family or colleagues. Following the Trio's voluntary acceptance of guilty pleas that ended their careers (as is usually the case), they mounted a "creative" legal argument that excluding the Trio from participation in federal programs must constitute due process violations. ${ }^{153}$

In fact, Purdue was likely not to keep the Trio in their respective, corporate positions in any event, and the guilty plea was likely to end their careers in the health sector even without the government's exclusion. This is so because federal sentencing guidelines specifically provide: "The organization shall use reasonable efforts not to include within the substantial authority personnel of the organization any individual whom the organization knew, or should have known through the exercise of due diligence, has engaged in illegal activities or other conduct inconsistent with an effective compliance and ethics program."154

\section{F. Considering and Accepting the Trio’s Guilty Plea}

The industry's reaction or concern arising out of the Trio's exclusions was overblown. Of note is the government's process of accepting guilty pleas in a criminal case with particular emphasis placed on plea agreements:

A corporation should be made to realize that pleading guilty to criminal charges constitutes an admission of guilt and not merely a resolution of an inconvenient distraction from its business. As with natural persons, pleas should be structured so that the corporation may not later "proclaim lack of culpability or even complete innocence." " 155 . . Thus, for instance, there should be placed upon the record a sufficient factual basis for the plea to prevent later corporate assertions of innocence. ${ }^{156}$

The same principles apply to individuals, of course. For this reason, it is appropriate to take the time and review the precise procedure that took place in that particular courtroom in Washington D.C. where the Court accepted the guilty pleas of the Trio. Following, possibly, months of negotiations with the prosecutors and with the support and advice of their attorneys, the Trio must have understood very clearly that accepting a guilty plea might precipitate the flow of other, likely unwelcomed, events.

${ }^{152}$ Id.; see also Crawford, supra note 12 , at 46.

153 Sebelius, 686 F.3d at 823-24 (D.C. Cir. 2012).

${ }^{154}$ U.S. SENTENCING GUIDELINES MANUAL, supra note 134, at $\S 8$ B2.1 at 513.

155 See USAM $\S \S 9-27.420$ (b)(4), 9-27.440, 9-27.500.

${ }^{156}$ Filip Memo, supra note 109, at Attachment 20. 
Before accepting a plea of guilty, the court was required to address each defendant personally in open court to determine if the defendant understood the ramifications of pleading guilty. The court was required to engage in lengthy colloquia with each of the Trio to ensure they understood the grave consequences that may flow from the plea. ${ }^{157}$ No person should have taken the guilty plea lightly and expect continued, uninterrupted employment, now as convicted criminals, in a position of trust at an organization.

\section{G. RCOD Resulting in Exclusion Does Not Violate Due Process}

In order to avail oneself of due process protections, there must be a cognizable and protected property interest that is being taken away, a right conferred by state law. ${ }^{158}$ Certain types of employment arrangements may rise to the level of a protected property interest. ${ }^{159}$ This is particularly true of public employees. ${ }^{160}$ However, the courts do not view the taking of an employment within the health industry as such a protected property interest.

A due process challenge entails a two-step analysis: "(1) whether plaintiff has been deprived of a protected interest in property or liberty; and (2) if such a deprivation is shown, whether the government's procedures comport with due process."161 Typically, exclusions from participation in federally funded programs do not implicate a protected interest in property, in that the exclusion does not affect the ability for the excluded individual to receive benefits under the entitlement programs (Medicare). ${ }^{162}$ Exclusion prohibits claiming payment from these federal programs for items or services rendered within employment context. ${ }^{163}$ Consequently, exclusion is likely to operate as an end to a career in the health industry. But "[i]f you cannot live the way you want, there's no point in living" 164 argument does not rise to the level of a cognizable deprivation of liberty under the Due Process clause.

The Supreme Court has upheld the constitutionality of strict liability crimes within the context of due process violation allegations, in part, because their associated penalties ". . . "commonly are relatively small, and conviction does no grave damage to an offender's reputation." 165 The latter point relative to lack of impact on reputation is not likely grounded in reality. The Court immediately corrected itself, however, recognizing that the exclusion may indeed have serious consequences, pointing out that the exclusionary provision is not a criminal statute and

157 FED. R. CRIM. P. 11(b).

${ }^{158}$ Cleveland Bd. of Educ. v. Loudermill, 470 U.S. 532, 538 (1985) (citing Bd. of Regents v. Roth, 408 U.S. 564, 573-78 (1972); Reagan v. United States 182 U.S. 419, 425 (1901); Memphis Light, Gas \& Water Div. v. Craft, 436 U.S. 1, 11-12 (1978); Goss v. Lopez, 419 U.S. 565, 573-74 (1975)).

159 See, e.g., id.

160 See id. at 538-39.

${ }^{161}$ Cardinal Health, Inc. v. Holder, 846 F. Supp. 2d 203, 229 (D.D.C. 2012) (citing Gen. Elec. Co. v. Jackson, 610 F.3d 110, 117 (D.C. Cir. 2010)).

162 Exclusions FAQ, supra note 103, at Does an Exclusion Affect a Person's Right to Receive Benefits Under the Medicare, Medicaid and all Federal Health Care Programs.

${ }^{163} \mathrm{Id}$.

164 Reinaldo Arenas \& Dolores M. Koch (Translator), Before Night Falls ix (Penquin Books, 1994).

${ }^{165}$ Sebelius, 686 F.3d at 824 (D.C. Cir. 2012) (citing 42 U.S.C. $§ 1320 a-7(b)(1)(2016)$ ). 
[e]xcluding an individual . . . on the basis of his conviction for a strict liability offense [does not] raise[s] any significant concern with due process. Exclusion effectively prohibits one from working for a government contractor or supplier. Surely the Government constitutionally may refuse to deal further with senior corporate officers .... 166

\section{H. Conflict of Interest and Indemnification}

The DOJ encourages complete and absolute cooperation and disclosure of the responsible individuals within those entities. ${ }^{167}$ Full disclosure requires a corporation "to locate and provide facts and evidence ... that implicate those individuals." 168 In fact, full disclosure and cooperation is codified under the False Claims Act, and according to the Yates Memo, will be interpreted as, "at a minimum, all relevant facts about responsible individuals must be provided."169 The Yates Memo further states that the full disclosure of responsible individuals will be integrated into certain criminal and civil provisions of the United States Attorney's Manual under the Principles of Federal Prosecution of Business Organizations and under the commercial litigation provisions, and "all future investigations of corporate wrongdoing" will include focus on individuals from the inception of investigations. ${ }^{170}$ Importantly, the Yates Memo makes it clear that U.S. attorneys should not enter into corporate agreements that would result in dismissal of charges or immunity to individuals. ${ }^{171}$

Although the corporation's expected full cooperation and disclosure of individuals may appear onerous at first, it actually protects innocent individuals that may have been otherwise falsely accused by their own corporations. Now, corporations will have to support the disclosure of individuals with culpable evidence against those individuals. As a quid pro quo, in exchange for full disclosure and timely cooperation, the DOJ ameliorates the maximum level of liability that could have been otherwise imposed on corporations. ${ }^{172}$

As companies settle their cases with government agencies, the relationship between the corporate officers and their respective entities may carry an inherent conflict of interest under such circumstances.

Under pressure to disclose purportedly culpable individuals to the DOJ, in order to increase its own chances at lower fines or penalties from the DOJ, corporations are enticed to point fingers at its own officers. Such a dynamic between the corporation and its officers, in a position of responsibility, may create divergent interests. At such a juncture, it is impossible for the same

${ }^{166} \mathrm{Id}$.

${ }^{167}$ Implications for U.S. Law on EU Practice, supra note 110.

${ }^{168}$ Memorandum from Sally Quillian Yates, Deputy Attorney Gen., United States, to Assistant Attorney Gens. For Antitrust, Civil, Criminal, Env't and Nat. Res., Nat'l Sec., and Tax Divisions, Dirs. of Fed. Bureau of Investigation, Exec. Office for U.S. Trustees, and All U.S. Attorneys, Individual Accountability for Corporate Wrongdoing 4, (Sept. 9, 2015), https://www.justice.gov [https://perma.cc/A47F-WUCL] [hereinafter Yates Memo].

${ }^{169} \mathrm{Id}$.

${ }^{170}$ Id. at 3.

${ }^{171}$ Id. at 5.

${ }^{172}$ Id. at 3. 
person to perform both roles effectively, to act in the best interests of the corporation, and simultaneously protect self-interest. Undoubtedly, the DOJ's desire to get to the bottom of the problems and eradicate them is understandable. But certainly, this particular approach may not foster a healthy and collegial relationship within the corporation, which may ultimately result in the wrong people being identified and innocent people on the hook for someone else's wrongful actions.

Additional conflicts of interest issues arise when a corporate officer (whether an owner or officer or director of the entity) is excluded, and then the government agency may exclude his or her entity as well. ${ }^{173}$ Likewise, once a company is convicted, it is likely that the OIG will next turn to the corporate officers themselves. To protect themselves from a possible attack on their individual wrongdoing, the purportedly responsible corporate officers may resort to a "noisy withdrawal," analogous to the "noisy withdrawal" of outside legal counsel in situations where their efforts to walk "up the ladder" with possible wrongdoing does not bring about appropriate response, as it is codified in the Sarbanes-Oxley Act ("SOX Act"). ${ }^{174}$

Further, the Yates Memo states that corporate cases should not be resolved without resolving individual cases, and the ability to charge individuals should be done without regard to "that individual's ability to pay." 175 In instances where a corporate officer has a mandatory indemnification agreement with the entity and seeks to enforce it, the courts have ruled in favor of an entity not to indemnify the officer in exclusion matters in front of the OIG. ${ }^{176}$ This particular pronouncement was based on the Delaware statute, which prohibits the indemnification of unsuccessful "bad actors." 177 This is not an unusual interpretation of the law. Therefore, in negotiating settlements with the OIG, counsel should be cognizant of whether a plea deal, even to a lesser offense, would constitute a "successful" settlement that would later entitle the individual to indemnification. ${ }^{178}$

Indemnification provisions are typically contractual in nature. However, the person that caused his or her own negligence or wrongful acts cannot invoke even contractual indemnification clauses, in that such indemnification is often viewed as against public policy and unenforceable. ${ }^{179}$ Importantly, "regulated businesses providing essential services to the public, such as hospitals, are subject to statutory or public policy restrictions against being indemnified for their own negligence." 180 As expected, when a corporation points a finger at the responsible corporate

17342 C.F.R. $§ 1001.1001$ (a)(1)(i)(C) (1999).

174 The Sarbanes Oxley Act, Pub. L. No. 107-204 § 205.3(d)(2), 116 Stat. 745 (2002).

175 Yates Memo, supra note 168, at 2-3.

${ }^{176}$ Hermelin v. K-V Pharm. Co., 54 A.3d 1093, 1115 (Del. Ch. 2012); see also William Jordan, Esq., Delaware Court Rules On Director's Entitlement To Indemnification For Expenses Incurred In Criminal Suit, Regulatory Action And Internal Investigation, 37 PROF'L LIAB. REPORTER art. 23 (March 2012).

${ }^{177}$ Hermelin, 54 A.3d at 1094 (Del. Ch. 2012).

${ }^{178}$ Elizabeth B. Burnett, Don't Win the Battle but Lose the War Retaining Directors' Mandatory Indemnification Rights in Settlements of Civil and Criminal Proceedings, 27 Westlaw J. CORPORATE OFFICERS \& DIR. LIAB. 1, 2-3 (2012).

${ }^{179}$ Stafford Matthews, Indemnification Clauses 68, Ass' N OF CORP. Counsel (Nov. 14, 2013), http://www.acc.com/ [https://perma.cc/24AC-XAMG].

${ }^{180}$ Id. (quoting, e.g., 215 ILCS 134/95 (Ill. 2000)). 
officer, it is certainly not going to step-up and indemnify that person the corporation said caused his own negligence. Consequently, indemnification provisions may not be very helpful to executives and Board Members pulled into the RCOD.

\section{COMPlance Programs ${ }^{181}$}

Compliance programs carry a two-fold purpose. First, compliance programs ensure easier compliance with the complex regulations, and in some healthcare sectors, such compliance is mandated by the Patient Protection and Accountable Care Act ("PPACA"). ${ }^{182}$ However, the second purpose of compliance programs is less obvious, and is certainly not mandated, but is very helpful whenever the government knocks on the door-it is to protect not the corporations but the individuals inside the corporations, those individuals in positions to influence decisions within the health-related organizations.

As previously mentioned, there are two types of defenses that can be asserted in RCOD cases. One type consists of affirmative defenses asserted during litigation, such as the "powerless" defense. ${ }^{183}$ The other type of defense that may be raised prior to litigation and during the investigation process, is the presence of an effective compliance program.

A compliance and ethics program is intended to prevent and detect criminal conduct. ${ }^{184}$ The requirements for an effective compliance and ethics program finds its roots in Section 805(a)(2)(5) of the SOX Act to ensure the guidelines that apply to organizations " are sufficient to deter and punish organizational criminal misconduct." 185 In 2002, in response to a series of accounting scandals involving U.S. companies, Congress enacted the SOX Act, which strengthened the accounting requirements for public companies. SOX Act Section 302 requires that a company's "principal [officers]" take responsibility for, and certify the integrity of, their company's financial reports on a quarterly basis. ${ }^{186}$

SOX Act compliance principles have been adopted throughout other high-risk industries including health-related industries. Federal sentencing guidelines provide the footprint for effective compliance programs, and state that a: "[c]ompliance and ethics program shall be reasonably designed, implemented, and enforced so that the program is generally effective in preventing and detecting criminal conduct." 187

${ }^{181}$ Some parts of this section have originally been published in: Jane Kim \& David Zakson, Health Information and Data Security Safeguards, 32 J. MARSHALl J. InFO. TECH. \& PRIVACY L. 133 (2016).

182 Patient Protection and Accountable Care Act, Pub.L. No. 111-148, § 6001, 124 Stat. 119, 689 (2010) (authorized the Secretary of HHS to mandate providers to have a compliance program); see David W. Hilgers, Esq. \& Sidney S. Welch, Esq., Physicians Post-PPACA: Not Going Bust At The Healthcare Buffet, 24 A.B.A. Health L. SEC. 1, 1-15 (Feb. 2012), http://www.americanbar.org [https://perma.cc/SAY8-7JJ3].

183 United States v. Park, 95 S. Ct. 1903, 1912 (1975), quoting, United States v. Wiesenfeld Warehouse Co., 376 U.S. 86, 91 (1964).

${ }^{184}$ U.S. SENTENCING GUIDELINES MANUAL, supra note 134, at ch.8, at 504.

${ }^{185} \mathrm{Id}$. at 517.

18615 U.S.C. $\S 7241(\mathrm{a})(2002)$.

${ }^{187}$ U.S. SENTENCING GUIDELINES MANUAL, supra note 134, at $\S 8$ B2.1 at 512. 
Importantly, "[ $\mathrm{t}]$ he existence of a corporate reporting system is a key compliance program element, which . . . keeps the Board informed of the activities of the organization . ..."188 But is it feasible to have a grip on what each employee is doing and communicating within large and publicly-held corporations in particular? Or, are the government's expectations of corporate officers in large organizations unrealistic and out of touch with reality?

The government's expectation, of corporate officers knowing what every individual is doing within the entity, can be realized with the existence of a robust and dynamic compliance and monitoring system. Effective compliance programs may also aid the executives in preserving their employment, careers and reputations. Likewise, proper compliance programs will serve to protect the entities from steep fines and exclusions that may flow from violations or breaches.

The OIG offers specific guidance on compliance programs for select healthcare sectors. ${ }^{189}$ The OIG states that, "at a minimum," compliance programs must contain and implement the following seven elements: (1) written policies and procedures; (2) the designation of a chief compliance officer; (3) training programs; (4) hotline to receive complaints; (5) appropriate discipline; (6) auditing and monitoring; and (7) investigation and remediation. ${ }^{190}$

When the OIG expanded upon each of the seven elements of the effective compliance plan by issuing "OIG guidance," it was certainly useful and did provide guidance to compliance officers. ${ }^{191}$ However, the word "guidance," coupled with the word "voluntary," are very misleading, in that such guidance has the force of law. ${ }^{192}$ Compliance programs are "evidence" of complying with the law. ${ }^{193}$ Compliance programs are "especially critical" in reimbursement and payment areas where fraud and abuse are more prevalent. ${ }^{194}$ It is "incumbent" upon the health industry and, especially, corporate officers to ensure that adequate programs "are in place to facilitate ethical and legal conduct." 195 In crafting its guidance, the OIG sought input from various interested parties within the health sector; essentially, prior to this guidance being issued, it was open for comment as if during the rule making process. ${ }^{196}$ It appears that the OIG promulgated law under the rubric of "guidance."

In addition to the OIG's "guidance," the DOJ emphasizes the distinction between whether a compliance plan is "real" or merely "paper." 197 The DOJ further addresses "practical aspects of

188 PRACTICAL GUIDANCE, supra note 85, at 2.

189 U.S. Off. of Inspector Gen, Compliance Guidance, U.S. DEP'T OF HeALTH AND Human SERVS, http://oig.hhs.gov/ [https://perma.cc/5AGV-DZ36] (last visited Nov. 14, 2016).

${ }^{190}$ Publication of the OIG Compliance Program Guidance for Hospitals, 63 Fed. Reg., 8987, 8989 (Feb. 23, 1998), http://oig.hhs.gov/authorities/docs/cpghosp.pdf [https://perma.cc/8CWUFKKL].

${ }^{191} \mathrm{Id}$.

${ }^{192} \mathrm{Id}$.

193 Federal Fraud Enforcement and Physician Compliance, AM. MED. Ass’N. (2000).

194 Publication of the OIG Compliance Program Guidance for Hospitals, 63 Fed. Reg., 8987, 988 (Feb. 23, 1998), http://oig.hhs.gov [https://perma.cc/8CWU-FKKL].

195 Id.

196 A Guide to the Rulemaking Process, OfFICE OF THE FEDERAL REGISTER, https://www.federalregister.gov [https://perma.cc/3WDE-KHDK].

${ }^{197}$ Michael W. Peregrine, DOJ's Important Message to Health System Leadership, AHLA, May 29, 2015, https://www.mwe.com [https://perma.cc/VMS8-XJYT]. 
management-employee interaction; i.e., whether employees are tacitly encouraged or pressured to engage in misconduct, or whether employees are encouraged to place "profits over compliance." "198

The United States Sentencing Guidelines Manual ("USSG") 199 aids federal judges with how to sentence corporations for criminal wrongdoing by providing formulas or a "Culpability Score" as a baseline to determine a sentence. ${ }^{200}$ The Culpability Score determines the entity's fine, measures the involvement of corporate officers in, or tolerance of, criminal activity within the organization. ${ }^{201}$ Effective compliance programs have a positive impact on the Culpability Score, which in turn may save the corporation multi-millions of dollars.

In addition to "guidance" on compliance plans, certain federal laws mandate the institution of policies and procedures within select types of organizations. For instance, the PPACA authorizes HHS to require providers participating in Medicare and Medicaid programs to establish a compliance program. ${ }^{202}$ Pursuant to HIPAA, covered entities and business associates are required to maintain certain administrative safeguards, such as the risk analysis, risk management, sanction policy and information system activity review. ${ }^{203}$ Although, it is required to implement administrative safeguards, having a compliance plan is largely not required under HIPAA. However, should a breach occur, a well-implemented compliance plan "provides evidence that any mistakes were inadvertent, and this evidence would be considered in determining whether a medical practice or other healthcare entity has made reasonable efforts to avoid and detect misbehavior."204

Additionally, under the Deficit Reduction Act of 2005 ("DEFRA"), Congress incentivized states to pursue Medicaid fraud under state statutes paralleling the federal False Claims Act ("FCA"). Under DEFRA, "[a]ny entity that receives or makes annual payments under the State plan of at least $\$ 5,000,000$, as a condition of receiving such payments shall—establish written policies and procedures [educating]" its employees, contractors and agents [about the FCA]. ${ }^{205}$ Similarly, CMS Medicare Part C \& D also requires educational programs. ${ }^{206}$

${ }^{198} I d$.

199 See U.S. SEntencing Guidelines §8C2.5. (U.S. SENTENCING COMM’N 2016); U.S.S.G $\S 8 \mathrm{C} 2.5$.

${ }^{200}$ Paula A. Tuffin, Effective Compliance and Ethics Programs Under the Amended Sentencing

Guidelines, A.B.A. 1 (2010), http://apps.americanbar.org [https://perma.cc/JYH5-42TG].

${ }^{201}$ U.S. SENTENCING GUIDELINES MANUAL, supra note 134, at $\S 8 \mathrm{C} 2.5$ at 524.

202 Patient Protection and Accountable Care Act, Pub.L. No. 111-148, § 6001, 124 Stat. 119, 751 (2010).

${ }^{203}$ Kim, supra note 36, at 9 (quoting Health Insurance Portability and Accountability Act of 1996, Pub. L. No. 104-101, §164.308(a)(a)(ii)(A-D)); quoting, HIPAA, §164.308.

204 Federal Fraud Enforcement and Physician Compliance, AMERICAN MEDICAL ASSOCIATION (2000). 20542 U.S.C.A. 1396a (a)(68) (2016).

206 Compliance Program Policy and Guidance, CMS.GOV, https://www.cms.gov/ [https://perma.cc/P437-K2NR] (last updated Jun. 15, 2016, 12:11 PM) ("Federal regulations at 42 C.F.R. $\S \S 422.503$ and 423.504 specify the requirements for Medicare Plans to implement an effective Compliance Program"). 
Fragmented efforts by the government to mandate some kind of training within certain organizations leaves guidance on compliance programs seemingly as an elective tool. The word "guidance" is somewhat misleading, however, in that it is in the best interests of the organizations to follow such guidance on how to properly structure compliance programs as if the guidance was mandated under law.

\section{CONCLUSION}

With the RCOD at its disposal, the government continues to increase its efforts to combat fraud and abuse within the health industry with much greater focus on individual responsibility. These efforts appear troubling, in that well-meaning individuals may feel threatened by the lack of legal safeguards in the application of the RCOD. Certainly, not having to prove the elements of intent and knowledge under the RCOD, in seeking misdemeanor criminal prosecutions is worrisome. A comforting thought is that the Yates Memo identified limited safeguards by requiring full disclosure of such individuals, meaning that it is not sufficient to simply identify individuals by name but that such disclosure must be accompanied by "all relevant facts relating to the individual responsible for the misconduct." 207 Thus, mere disclosure of individuals' names is not sufficient; corporations must provide evidence of culpable conduct.

However, the RCOD does not provide sufficient legal safeguards, if at all, to defend those individuals in a court of law, in that no knowledge or intent is required to be proven as an element of the misdemeanor charge. The public policy question is: Should the public welfare overcome individual liberties and livelihoods in these situations? The Courts have answered- Yes, in such regard.

Given the relaxed legal elements of a RCOD criminal charge, it should not be a standalone, independent cause of action. The RCOD should be contingent on, or coupled with, another legal cause of action against that individual's corporation. In doing so, responsible corporate officers are not charged, convicted and sentenced to a maximum of six months in prison under such relaxed rules, but are convicted only if their respective corporation is convicted with at least a misdemeanor offense as well. Importantly, charges against corporations carry the requisite elements expected for criminal convictions, including knowledge and intent. If the government is able to prove elements of intent and knowledge against the corporation then doing away with the same burden of proof against the linked individuals would not be as offensive. After all, corporations can only act through individuals. Therefore, the RCOD should only be a coupled cause of action.

Further, for cases that involve inadvertent or unintentional non-compliance, individuals and corporations should not be automatically subject to criminal investigation and should be treated differently from criminals intending to break the law for their own personal gain. This would seem a fair and morally correct approach.

Given the existing government focus and the wide reach of the RCOD, individuals likely to be impacted by the RCOD must proactively safeguard against it. In doing so, individuals should become familiar with the detailed government guidelines for corporations and individuals and ensure that every single item on those lists is checked. ${ }^{208}$ Individuals should not engage in passive management while relying on contractual indemnification provisions, in that those do not work in the RCOD cases. Every responsible corporate officer should ensure that there is a robust and effective compliance program capable of timely detecting wrongdoings and further ensuring that timely and corrective measures have been implemented. Genuine compliance programs are one of

${ }^{207}$ Yates Memo, supra note 168, at 2.

208 See Filip Memo, supra note 109. 
the most effective ways to avoid becoming a target under the RCOD. Taking proactive measures will help separate responsible corporate officers from common criminals. 